\title{
FOGLALKOZTATÓK ÉS FOGLALKOZTATOTTAK A HAZAI ZÖLDSÉG-GYÜMÖLCS FELDOLGOZÓIPARBAN
}

\author{
- ho
EMPLOYERS AND EMPLOYEES IN THE DOMESTIC VEGETABLE-FRUIT MANUFACTURING INDUSTRY \\ KURMAI, Viktória \\ - \\ Debreceni Egyetem, Gazdaságtudományi Kar, Gazdálkodástudományi Intézet, \\ Üzemtani és Vállalati Tervezés Tanszék \\ (University of Debrecen, Faculty of Economics and Business, Institute of Management Sciences, \\ Department of Farm Business Management and Corporate Planning) \\ H-4032 Debrecen, Böszörményi út 138 . \\ e-mail: kurmaiviki@agr.unideb.hu
}

In the light of KSH databases processing, it can be said, that the food industry has the largest significance on the employment in the manufacture industry. The number of employees in fruit and vegetables manufacturing industry has decreased drastically while the number of part -time workers has increased since the turn of the millenium. Two classes of the examined subsector represent high indexes by the value of marketed product per emloyee. The number of businesses in fruit and vegetable manufature industry hasn't changed radically, but the small and medium-sized enterprises became to the force.

\section{BEVEZETÉS - INTRODUCTION}

A zöldség-gyümölcs szektor a mezőgazdaság egyik legfejlődőképesebb és legnagyobb munkahelyteremtő ágazata [2]. A mezőgazdasági terület mindösszesen 4-5\%-át foglalja el, de magas kézi munkaerő igénye miatt a foglalkoztatásban betöltött szerepe ennél jóval jelentősebb [4]. A magyar zöldség-gyümölcs feldolgozóipar az utóbbi húsz évben kapacitásainak jelentős részét elvesztette [1]. A termelés jelenleg 1,4 millió tonna körül mozog, ami jelentős csökkenés az 1980-as évekhez képest. A visszaesésért felelős a feldolgozás csökkenése, valamint a kereskedelmi és technológiai fejlesztések hiánya is [5].

A tanulmányban szeretném meghatározni a zöldség-gyümölcs feldolgozóipar jelentőségét az élelmiszeriparban, különös tekintettel a foglalkoztatottak és a vállalkozások mennyiségi változására és összetételére. A tanulmányban a célkitűzésem, hogy meghatározzam a zöldség-gyümölcs feldolgozóiparban a foglalkoztatottak számát, annak változását és összetételét. Értékelni szeretném a termelés csökkenésének köszönhetően mekkora változás következett be a vállalkozások számában és létszám-kategóriánkénti összetételében.

\section{ANYAg ÉS MÓDSZER - MATERIALS AND METHODS}

A tanulmányhoz szükséges adatbázisokat a KSH szolgáltatta. A KSH honlapján elérhető tájékoztatási adatbázis adattábláit használtam, melyek 2000 és 2013 közötti adatokat dolgoztak fel, egyes esetben térek csak ki a 90-es évekre. Az adatokat Microsoft Excel programban összegeztem és elemeztem. A vállalkozások számát a KSH 2013-as „Müködő, valódi új, valódi megszűnt vállalkozások száma nemzetgazdasági ág szerint” elnevezésü adatbázisból szereztem, melyből én a múködő vállalkozások számát vettem alapul a bemutatáshoz. A foglalkoztatás jellemzéséhez a 2013-as „Foglalkoztatottak száma nemzetgazdasági ágak, ágazatok szerint” táblákat alkalmaztam. Ezeken kívül a munkaügyi és a foglakoztatási adatokhoz, a KSH 2014-es „Nemzetgazdaság munkaügyi adatai” adatbázist használtam. A vállalkozások tekintetében az „Éves gazdaságszerkezeti adatok létszám kategóriánként” adatbázist használtam. A zöldség-gyümölcs feldolgozóipar vállalkozásainak és a foglalkoztatottjainak bemutatásához leíró statisztikai módszereket alkalmaztam, az adatokat táblázatokkal és diagramokkal szemléltettem. 


\section{FOgLALKozTATÁSi ADATOK - EMPLOYMENTS' DATA}

$\mathrm{Az}$ élelmiszergyártás egy munkaerő igényes ágazat. Az utóbbi időben azonban az évról évre csökkenő számú múködő vállalkozások és a folyamatos gépesítés, illetve a pénzügyi nehézségekből adódó létszámleépítések miatt egyre kevesebb embert foglalkoztat [3]. Az élelmiszeripar foglalkoztatja a legtöbb embert a feldolgozóiparban, eközben a nemzetgazdaságban betöltött szerepe folyamatosan csökken.

Az 1. táblázatban az ital- és dohánygyártás nélkül látható az élelmiszeriparban foglalkoztatottak száma, valamint zöldség-gyümölcs feldolgozóiparban dolgozók megoszlása. Látható, hogy számuk csaknem megfeleződött és az élelmiszeripari részarányuk is 11,4\%-ról 8,7\%-ra csökkent a vizsgált időszakban. 2009 óta a zöldség-gyümölcs feldolgozóiparban foglalkoztatottak számában stagnálás, talán előre vetíthető növekedés tapasztalható. Míg az élelmiszeriparban foglalkoztatottak száma 33\%-kal csökkent, addig az általam vizsgált szakágazatban 41\%-os csökkenés tapasztalható 2013-ban a 2000. éves adatokhoz képest.

A zöldség-gyümölcs feldolgozóiparban a 200o. évi adatokat tekintve 79\%-os arányban fizikai foglalkozásúakat, 18\%-ban szellemi foglalkozásúakat és 3\%-ban egyéb, illetve nem teljes munkaidőben foglalkoztatottakat különböztethetünk meg. Mára ez az arány a foglalkoztatottak 41\%-os csökkenése mellett a 69:20:11-es arányt képvisel. Míg a szellemi foglalkozásúak száma arányosan csökkent a foglalkoztatottakkal összehasonlítva, addig a fizikai foglalkoztatásúak száma nagyobb arányban csökkent, illetve az egyéb és nem teljes munkaidőben foglalkoztatottak aránya megduplázódott.

Amennyiben kiemeljük a hütő és konzervipart és öszszehasonlítjuk a többi szakágazattal megállapítható, hogy az egyéb zöldség és gyümölcs feldolgozás, -tartósítás szakágazat az ötödik legtöbb embert foglalkoztató szakágazat, a huszonöt szakágazatból jelenleg 8\%-ot foglalkoztat.

A 2. táblázatban két mutatót képeztem a foglalkoztatásra vonatkozóan annak érdekében, hogy meghatározzam a zöldség-gyümölcs feldolgozóipar munkaerő igényességének mértékét, illetve, hogy összevessem ezeket az adatokat a többi élelmiszeripari szakágazattal.

A két mutató szorosan összefügg és az egy före jutó termelési érték növekedésével fordított arányban csökken az 1 milliárd Ft termelési értékre jutó alkalmazotti létszám. A zöldség-, gyümölcsfeldolgozó és -tartósító alágazat két legjelentősebb szakágazata a rangsor első felében helyezkednek el. Elmondható, hogy az egy alkalmazottra jutó termelési értéke a gyümölcs-, zöldséglé gyártó szakágazatnak a harmadik legmagasabb, azaz kevesebb ember is elégséges a termékek előállításához. Azonban az egyéb gyümölcs-, zöldségfeldolgozás,

-tartósítás szakágazat termelési értéke alapján a negyedik legjelentősebb. A munkaerőigénye közepesnek mondható a többi szakágazathoz képest. Ez alapján megállapítható, hogy ez a szakágazat, melyet fóleg a hütő és konzervipari cégek képviselnek az olaj-, a baromfihús-, a hús-, és a tejtermékek gyártása mellett a legjobb termelési érték-munkaerő arányba teljesítő szakágazat.

1. TÁBLÁZAT

TABLE 1

A hazai zöldség-gyümöles feldolgozóiparban foglalkoztatottak aránya az élelmiszeriparban (The Employment Rate of Domestic Fruit and Vegetable Manufacturing Industry in Food Industry)

\begin{tabular}{|c|c|c|c|}
\hline $\begin{array}{c}\text { Évek } \\
\text { (Years) }\end{array}$ & $\begin{array}{l}\text { Gyümölcs-, zöldségfeldolgozás, -tartósítás } \\
\text { alágazat, fö (Subsector of processing } \\
\text { and preserving offruit and vegetables, } \\
\text { capita) }\end{array}$ & $\begin{array}{l}\text { Élelmiszergyártás, fö } \\
\text { (Food industry, capita) }\end{array}$ & $\begin{array}{l}\text { Részarány, \% } \\
\text { (Share, \%) }\end{array}$ \\
\hline 2002 & 12770 & 112460 & 11,4 \\
\hline 2003 & 12303 & 110598 & 11,1 \\
\hline 2004 & 11040 & 101477 & 10,9 \\
\hline 2005 & 10184 & 99209 & 10,3 \\
\hline 2006 & 9105 & 93681 & 9,7 \\
\hline 2007 & 8506 & 90477 & 9,4 \\
\hline 2008 & 7621 & 90128 & 8,5 \\
\hline 2009 & 7271 & 85531 & 8,5 \\
\hline 2010 & 7218 & 86630 & 8,3 \\
\hline 2011 & 7218 & 85862 & 8,4 \\
\hline 2012 & 6859 & 84562 & 8,1 \\
\hline 2013 & 7327 & 84434 & 8,7 \\
\hline
\end{tabular}

Forrás (Source): [7] 
Az élelmiszeripari szakágazatok foglalkoztatási mutatói 2012-ben (Employment Indexes in Classes of Food Industry in 2012)

\begin{tabular}{|c|c|c|}
\hline $\begin{array}{l}\text { Szakágazatok } \\
\text { (Classes) }\end{array}$ & $\begin{array}{c}1 \text { alkalmazottra } \\
\text { jutó termelési } \\
\text { érték, millió Ft } \\
\text { (The value of } \\
\text { marketed product } \\
\text { per emloyee, } \\
\text { million HUF) }\end{array}$ & $\begin{array}{c}1 \text { milliárd Ft } \\
\text { termelési értékre } \\
\text { jutó alkalmazott, } \\
\text { fö (Employee } \\
\text { per one billion } \\
\text { production value, } \\
\text { capita) }\end{array}$ \\
\hline Olaj gyártása (Manufacture of oils and fats) & 222,3 & 4 \\
\hline Haszonállat-eledel gyártása (Manufacture of prepared feeds for farm animals) & 58,5 & 17 \\
\hline Gyümölcs-, zöldséglé gyártása (Manufacture of fruit and vegetable juice) & 54,9 & 18 \\
\hline $\begin{array}{l}\text { Malomipari termék gyártása (Manufacture of grain mill products, starches and } \\
\text { starch products) }\end{array}$ & 50,9 & 20 \\
\hline Hobbiállat-eledel gyártása (Manufacture of prepared pet foods) & 47,0 & 21 \\
\hline Tea, kávé feldolgozása (Processing of tea and coffee) & 39,9 & 25 \\
\hline Tejtermék gyártása (Operation of dairies and cheese making) & 35,4 & 28 \\
\hline $\begin{array}{l}\text { Baromfihús feldolgozása, tartósítása (Processing and preserving of poultry } \\
\text { meat) }\end{array}$ & 29,7 & 34 \\
\hline $\begin{array}{l}\text { Egyéb gyümölcs-, zöldségfeldolgozás, -tartósítás (Other processing and } \\
\text { preserving of fruit and vegetables) }\end{array}$ & 29,0 & 34 \\
\hline $\begin{array}{l}\text { Homogenizált, diétás étel gyártása (Manufacture of homogenised food } \\
\text { preparations and dietetic food) }\end{array}$ & 28,3 & 35 \\
\hline Húsfeldolgozás, -tartósítás (Processing and preserving of meat) & 24,8 & 40 \\
\hline Jégkrém gyártása (Manufacture of ice cream) & 23,4 & 43 \\
\hline $\begin{array}{l}\text { Hús-, baromfihús-készítmény gyártása (Production of meat and poultry meat } \\
\text { products) }\end{array}$ & 22,2 & 45 \\
\hline $\begin{array}{l}\text { Tésztafélék gyártása (Manufacture of macaroni, noodles, couscous and similar } \\
\text { farinaceous products) }\end{array}$ & 20,8 & 48 \\
\hline $\begin{array}{l}\text { Tartósított lisztes áru gyártása (Manufacture of rusks and biscuits; manufacture } \\
\text { of preserved pastry goods) }\end{array}$ & 19,4 & 52 \\
\hline Füszer, ételízesítő gyártása (Manufacture of condiments and seasonings) & 18,7 & 53 \\
\hline Burgonyafeldolgozás, -tartósítás (Processing and preserving of potatoes) & 14,6 & 68 \\
\hline Édesség gyártása (Manufacture of cocoa, chocolate and sugar confectionery) & 14,0 & 72 \\
\hline $\begin{array}{l}\text { Halfeldolgozás, -tartósítás (Processing and preserving of fish, crustaceans and } \\
\text { molluscs) }\end{array}$ & 10,6 & 95 \\
\hline M.n.s. egyéb élelmiszer gyártása (Manufacture of other food products n.e.c.) & 9,2 & 108 \\
\hline $\begin{array}{l}\text { Kenyér; friss pékáru gyártása (Manufacture of bread; manufacture of fresh } \\
\text { pastry goods and cakes) }\end{array}$ & 4,8 & 208 \\
\hline
\end{tabular}

Forrás (Source): [8; 10]

\section{VÁLLALKOZÁSOK JELLEMZÉSE - THE CHARACTERISTICS OF ENTERPRISES}

A múködő élelmiszeripari vállalkozások száma a nemzetgazdaságban található vállalkozások mindösszesen 1\%-át adja 2003 óta és a 2007-es mélypontját követően növekvő részesedést mutat [6]. Azonban a múködő élelmiszeripari vállalkozások száma a 2003. évihez képest 2007-ben 9\%-kal, míg 2012-ben 5\%-kal csökkent. Ennek oka, hogy a valódi új vállalkozások száma elmaradt a megszűnt vállalkozások számától az utóbbi 10 évben.

A 3. táblázatban az élelmiszergyártásban múködő vállalkozások számát összesítettem az ital- és dohánygyártó vállalkozások arányának figyelmen kívül hagyásá- val. A zöldség-gyümölcs feldolgozóiparban múködő vállalkozások száma növekszik, eközben az élelmiszeripari vállalkozások száma csökken, ezért egyértelmúen növekszik a részesedése.

A zöldség-gyümölcs feldolgozóiparban múködő vállalkozások döntő többsége kis- és mikrovállalkozás. Az elmúlt tíz évben a 250 fó feletti vállalkozások száma az egyharmadára csökkent, illetve az 50 és 250 fó közötti munkaerőt foglalkoztatók száma 40\%-kal csökkent. Ezzel párhuzamosan a kisebb létszám-kategóriájú cégek száma enyhe növekedést mutatott. A vállalkozások száma az utóbbi 10 évben lényegében nem változott. Viszont a létszám-kategóriák szerinti bontásból látszik (3. táblázat), hogy a kis- és mikrovállalkozások kerültek előtérbe. Egy vállalkozásra 2001-ben átlagosan huszonhárom fő jutott, 
addig 2011-ben tizenöt alkalmazott. A nagy vállalkozások megszűnése maga után vonta a foglalkoztatottak számának csökkenését is.

A zöldség-gyümölcs feldolgozóipari árbevétel csaknem felét a 2001. évben tizenhat 250 fő feletti vállalkozás adta, mára ez az arány lecsökkent 35\%-ra, amit mindöszszesen öt vállalkozás képez. Ezt azt jelenti, hogy az öt legnagyobb vállalkozás az alágazat árbevételéhez 7\%-7\%-kal járul hozzá. A második legnagyobb létszám-kategóriával (50-249 fő között foglalkoztatott) rendelkező vállalkozások járulnak hozzá legnagyobb arányban az árbevételhez, ami 2011-ben 44\%-os megoszlást jelent. A legtöbb vállalkozással rendelkező kis- és mikrovállalkozások kategória mindösszesen $20 \%$-kal részesedik a zöldség-gyümölcs feldolgozóipar árbevételéből, azaz a múködő vállalkozások 93\%-a adja az árbevétel 20\%-át.

A vizsgált szakágazat 2011-ben a legtöbb embert Bács-Kiskun megyében foglalkoztatja, de a 250 fó feletti vállalkozások még Pest, Hajdú Bihar és Jász-Nagykun-Szolnok megyében találhatóak. A második legtöbb mikrovállalkozás (azok közül is az 1-4 főt foglalkoztatóak) Szabolcs-Szatmár-Bereg megyében találhatóak, de a nagyobb létszám-kategóriájú vállalkozások jelentős része is ebben a megyében van. A 2011. évben a fent említett öt megyére koncentrálódik a zöldség-gyümölcs feldolgozóipar, mely leginkább az alapanyag termelés közelségének köszönhető.

3. TÁBLÁZAT

A zöldség-gyümölcs feldolgozóipari múködő vállalkozások száma és árbevétele létszám-kategóriánként

(The Number and Revenue of Running Businesses in Fruit and Vegetable Manufature Industry of Categories of Manpower)

\begin{tabular}{|c|c|c|c|c|c|c|}
\hline & & 2001 & & & 2011 & \\
\hline $\begin{array}{l}\text { Létszám- } \\
\text { kategóriák, fö } \\
\text { (Categories } \\
\text { of manpower, } \\
\text { capita) }\end{array}$ & $\begin{array}{c}\text { Múködő } \\
\text { vállalkozások } \\
\text { száma, db } \\
\text { (Running } \\
\text { businesses, } \\
\text { pieces) }\end{array}$ & $\begin{array}{c}\text { Nettó } \\
\text { árbevétel, } \\
\text { milliárd Ft } \\
\text { (Net revenue, } \\
\text { million HUF) }\end{array}$ & $\begin{array}{c}\text { Árbevétel } \\
\text { megoszlása, \% } \\
\text { (Distribution } \\
\text { of revenue, } \\
\%)\end{array}$ & $\begin{array}{c}\text { Múködő } \\
\text { vállalkozások } \\
\text { száma, db } \\
\text { (Running } \\
\text { businesses, } \\
\text { pieces) }\end{array}$ & $\begin{array}{c}\text { Nettó } \\
\text { árbevétel, } \\
\text { milliárd Ft } \\
\text { (Net revenue, } \\
\text { million HUF) }\end{array}$ & $\begin{array}{c}\text { Árbevétel } \\
\text { megoszlása, \% } \\
\text { (Distribution } \\
\text { of revenue, } \\
\%)\end{array}$ \\
\hline $1-9$ & 393 & 6,5 & 4 & 420 & 20,8 & 9 \\
\hline $10-19$ & 36 & 3,9 & 2 & 46 & 11,3 & 5 \\
\hline $20-49$ & 28 & 8,4 & 5 & 25 & 13,6 & 6 \\
\hline $50-249$ & 50 & 79,0 & 43 & 31 & 98,4 & 44 \\
\hline 250 és afelett & 16 & 84,7 & 46 & 5 & 79,2 & 35 \\
\hline Összesen & 523 & 182,5 & 100 & 527 & 223,3 & 100 \\
\hline
\end{tabular}

Forrás (Source): [9]

\section{5. ÖSSZEFOGLALÁS - SUMMARY}

A KSH adatbázisok elemzése alapján elmondható, hogy az élelmiszeripar a feldolgozóipari ágazatink közül a foglalkoztatás területén bír a legnagyobb jelentőséggel. A zöldség-gyümölcs feldolgozóiparban dolgozók száma az ezredforduló óta drasztikusan csökken, miközben egyre növekszik a szellemi és részmunkaidős foglalkoztatásúak aránya. A vizsgált alágazat két szakágazattal kapcsolatban kiemelkedően magas mutatókkal rendelkezik az egy alkalmazottra jutó termelési értéke alapján. A zöldség-gyümölcs feldolgozóipari vállalkozások száma nagyságrendekkel nem változott, azonban a kis és középvállalkozások előtérbe kerültek.

\section{IRODALOMJEGYZÉK - REFERENCES}

[1] Erdészné F. - Jankuné K. Gy. - Kozak A. Radócziné K. T.: A zöldség- és gyümölcságazat helyzete. Budapest, Agrárgazdasági Kutató Intézet, 2009. 39-48.

[2] Fodor Z.: Évértékelő kiadvány. Fruitveb. 2003-2012.

[3] Fórián Z.: A tartósítóipar helyzete és kilátásai Magyarországon. Agrár Európa Kft., Budapest, 2005.
[4] Fórián Z.:AZ EU-csatlakozás vesztese: a magyarországi élelmiszeripar. Agrár Európa Kft., Budapest, 2009.

[5] Gyarakay Z.: A magyar élelmiszeripar helyzete és megújulásának lehetőségei. In: Minőség és megbízhatóság. 2013. 46 (4) 148-155.

[6] KSH: Működő, valódi új, valódi megszűnt vállalkozások száma nemzetgazdasági ág szerint. 2013. URL: http://statinfo.ksh.hu/Statinfo/themeSelector. jsp?page=2\&szst=QVD (Letöltés dátuma: 2014 . augusztus 10.)

[7] KSH: Foglalkoztatottak száma nemzetgazdasági ágak, ágazatok szerint. 2013. URL: http://statinfo.ksh. $\mathrm{hu} /$ Statinfo/themeSelector.jsp ? page $=2 \&$ szst $=\mathrm{QLF}$ (Letöltés ideje: 2014. augusztus 10.

[8] KSH: Nemzetgazdaság munkaügyi adatai. 2014. URL: http://statinfo.ksh.hu/Statinfo/themeSelector. jsp?page $=2 \&$ szst $=$ QLI (Letöltés ideje: 2014 . augusztus 10.)

[9] KSH: Éves gazdaságszerkezeti adatok létszám kategóriánként. 2012. URL: http://statinfo.ksh. hu/Statinfo/themeSelector .jsp ? page $=2 \&$ szst $=$ QTA (Letöltés ideje: 2014. augusztus 10.)

[10] KSH: Ipari termékek és szolgáltatások éves termelése. 2012. URL: http://statinfo.ksh.hu/Statinfo/ themeSelector.jsp?page=2\&szst=OID (Letöltés ideje: 2014. augusztus 10.) 